\section{Michigan Technological

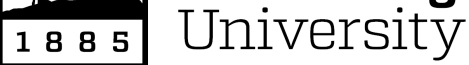

Michigan Technological University Digital Commons @ Michigan Tech

4-12-2001

\title{
Observations of volcanic clouds in their first few days of atmospheric residence: The 1992 eruptions of crater peak, Mount Spurr volcano, Alaska
}

\author{
William I. Rose \\ Michigan Technological University \\ Gregg J. Bluth \\ Michigan Technological University \\ David J. Schneider \\ U.S. Geological Survey \\ Gerald G. J. Ernst \\ University of Bristol \\ Colleen M. Riley \\ Michigan Technological University
}

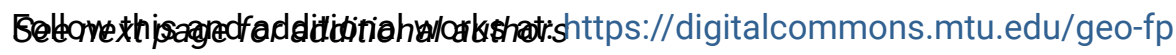

Part of the Geology Commons, Mining Engineering Commons, and the Other Engineering Commons

\section{Recommended Citation}

Rose, W. I., Bluth, G. J., Schneider, D. J., Ernst, G. G., Riley, C. M., Henderson, L. J., \& McGimsey, R. G. (2001). Observations of volcanic clouds in their first few days of atmospheric residence: The 1992 eruptions of crater peak, Mount Spurr volcano, Alaska. Journal of Geology, 109(6). http://dx.doi.org/ $10.1086 / 323189$

Retrieved from: https://digitalcommons.mtu.edu/geo-fp/71

Follow this and additional works at: https://digitalcommons.mtu.edu/geo-fp 


\section{Authors}

William I. Rose, Gregg J. Bluth, David J. Schneider, Gerald G. J. Ernst, Colleen M. Riley, Lydia J. Henderson, and Robert G. McGimsey 


\title{
ARTICLES
}

\section{Observations of Volcanic Clouds in Their First Few Days of Atmospheric Residence: The 1992 Eruptions of Crater Peak, Mount Spurr Volcano, Alaska}

\author{
William I. Rose, Gregg J. S. Bluth, David J. Schneider, ${ }^{1}$ Gerald G. J. Ernst, ${ }^{2}$ \\ Colleen M. Riley, Lydia J. Henderson, ${ }^{2}$ and Robert G. McGimsey ${ }^{1}$ \\ Department of Geological Engineering and Sciences, Michigan \\ Technological University, Houghton, Michigan 49931, U.S.A. \\ (e-mail:raman@mtu.edu)
}

\begin{abstract}
A B S T R A C T
Satellite $\mathrm{SO}_{2}$ and ash measurements of Mount Spurr's three 1992 volcanic clouds are compared with ground-based observations to develop an understanding of the physical and chemical evolution of volcanic clouds. Each of the three eruptions with ratings of volcanic explosivity index three reached the lower stratosphere $(14 \mathrm{~km}$ asl), but the clouds were mainly dispersed at the tropopause by moderate to strong $(20-40 \mathrm{~m} / \mathrm{s})$ tropospheric winds. Three stages of cloud evolution were identified. First, heavy fallout of large $(>500 \mu \mathrm{m})$ pyroclasts occurred close to the volcano $(<25 \mathrm{~km}$ from the vent) during and immediately after the eruptions, and the cloud resembled an advected gravity current. Second, a much larger, highly elongated region marked by a secondary-mass maximum occurred 150-350 km downwind in at least two of the three events. This was the result of aggregate fallout of a bimodal size distribution including fine $(<25 \mu \mathrm{m})$ ash that quickly depleted the solid fraction of the volcanic cloud. For the first several hundred kilometers, the cloud spread laterally, first as an intrusive gravity current and then by wind shear and diffusion as downwind cloud transport occurred at the windspeed (during the first 18-24 h). Finally, the clouds continued to move through the upper troposphere but began decreasing in areal extent, eventually disappearing as ash and $\mathrm{SO}_{2}$ were removed by meteorological processes. Total $\mathrm{SO}_{2}$ in each eruption cloud increased by the second day of atmospheric residence, possibly because of oxidation of coerupted $\mathrm{H}_{2} \mathrm{~S}$ or possibly because of the effects of sequestration by ice followed by subsequent $\mathrm{SO}_{2}$ release during fallout and desiccation of ashy hydrometeors. $\mathrm{SO}_{2}$ and volcanic ash travelled together in all the Spurr volcanic clouds. The initial (18-24 h) area expansion of the clouds and the subsequent several days of drifting were successfully mapped by both $\mathrm{SO}_{2}$ (ultraviolet) and ash (infrared) satellite imagery.
\end{abstract}

\section{Introduction}

The 1992 eruptions of the Crater Peak vent of Mount Spurr, Alaska (hereafter called "Spurr eruptions"), provided an opportunity to apply satellite measurement techniques to study the atmospheric residence of and fallout from volcanic eruption 2001.

Manuscript received January 23, 2001; accepted April 12,

${ }^{1}$ U.S. Geological Survey, Alaska Volcano Observatory, Anchorage, Alaska, U.S.A.

${ }^{2}$ Centre for Environmental and Geophysical Flows, Department of Earth Sciences, University of Bristol, Bristol BS8 1RJ, United Kingdom. clouds. Because of proximity to Anchorage and availability of the resources of the Alaska Volcano Observatory (a consortium of USGS, State of Alaska, University of Alaska Fairbanks) and the National Weather Service (National Oceanic and Atmospheric Administration), unusually complete basic observations existed. Here we integrate data on the eruptions from meteorological radar (Rose et al. 1995b), total ozone mapping spectrometer (TOMS) satellite observations (Bluth et al. 1995), advanced very high resolution radiometer (AVHRR) weather satellite data (Schneider et al. 1995; Shan-

[The Journal of Geology, 2001, volume 109, p. 677-694] @ 2001 by The University of Chicago. All rights reserved. 0022-1376/2001/10906-0001\$01.00 
Table 1. Characteristics and Environmental Conditions for the Crater Peak Eruptions of Mount Spurr, 1992

\begin{tabular}{|c|c|c|c|c|}
\hline & June 27 & August 19 & September 17 & Source \\
\hline Start time (GMT) & 1504 & 0042 & 2003 & 1 \\
\hline Eruption peak (GMT) & 1823 & 0055 & 2221 & 2 \\
\hline End time (GMT) & 1907 & 0410 & 2339 & 1 \\
\hline Duration (min) & 243 & 208 & 216 & 1 \\
\hline Mean column height ( $\mathrm{km}$ asl) & 11.1 & 11.8 & 12.0 & 3 \\
\hline Maximum column height (km asl) & 14.5 & 13.7 & 13.9 & 2 \\
\hline Mean eruption rate $\left(\mathrm{m}^{3} / \mathrm{s}\right)$ & 820 & 1120 & 1160 & $3,4,6$ \\
\hline Maximum eruption rate $\left(\mathrm{m}^{3} / \mathrm{s}\right)$ & 3230 & 2330 & 2500 & 2,4 \\
\hline Clast density $\left(\mathrm{kg} / \mathrm{m}^{3}\right)$ & 1760 & $1500-1550$ & $1530-1580$ & 3 \\
\hline \multicolumn{5}{|l|}{ Windspeed $(\mathrm{m} / \mathrm{s})$ : } \\
\hline $0-3 \mathrm{~km}$ asl & 5.8 & 6.5 & 5.2 & 5 \\
\hline $3-6 \mathrm{~km}$ asl & 16.2 & 12.3 & 15.1 & 5 \\
\hline 6-9 $\mathrm{km}$ asl & 18.6 & 18.6 & 29.3 & 5 \\
\hline $9-12 \mathrm{~km}$ asl & 21.3 & 24.9 & 36.4 & 5 \\
\hline $12-15 \mathrm{~km}$ asl & 13.9 & 10.9 & 32.3 & 5 \\
\hline \multicolumn{5}{|l|}{ Average wind direction: } \\
\hline $0-3 \mathrm{~km}$ & 169 & 205 & 153 & 5 \\
\hline $3-6 \mathrm{~km}$ & 190 & 290 & 239 & 5 \\
\hline $6-9 \mathrm{~km}$ & 200 & 315 & 274 & 5 \\
\hline $9-12 \mathrm{~km}$ & 202 & 308 & 272 & 5 \\
\hline $12-15 \mathrm{~km}$ & 201 & 275 & 276 & 5 \\
\hline Tropopause height (km asl) & 11.7 & 10.7 & 12.2 & 5 \\
\hline \multicolumn{5}{|l|}{ Temperature $\left({ }^{\circ} \mathrm{C}\right)$ : } \\
\hline $0 \mathrm{~km}$ asl & 10.2 & 15.2 & 4.3 & 5 \\
\hline $3 \mathrm{~km}$ asl & -2.8 & -7.2 & -7.0 & 5 \\
\hline $6 \mathrm{~km}$ asl & -19 & -23 & -16 & 5 \\
\hline $9 \mathrm{~km}$ asl & -41.7 & -47 & -39.9 & 5 \\
\hline $12 \mathrm{~km}$ asl & -57.3 & -62.3 & -62 & 5 \\
\hline \multicolumn{5}{|l|}{ Dew point $\left({ }^{\circ} \mathrm{C}\right)$ : } \\
\hline $0 \mathrm{~km}$ & 9.3 & 8.0 & -9.4 & 5 \\
\hline $3 \mathrm{~km}$ & -3.8 & -8.3 & -18 & 5 \\
\hline $6 \mathrm{~km}$ & -23 & -34 & -17 & 5 \\
\hline Fall volume (DRE $\left.\left[\times 10^{6} \mathrm{~m}^{3}\right]\right)$ & 12 & 14 & 15 & 3 \\
\hline
\end{tabular}

Sources. 1, McNutt et al. 1995, p. 165; 2, Rose et al. 1995b, p. 21; 3, Neal et al. 1995, p. 68; 4, Sparks et al. 1997, p. 118; 5, National Oceanic and Atmospheric Association rawindsonde information from Anchorage, Alaska; 6, Gardner et al. 1998.

non 1996), ash sampling (Neal et al. 1995; Gardner et al. 1998; McGimsey et al. 2001), and a wide variety of other geophysical observations (Keith 1995). The goal of this article is to gain better understanding of volcanic clouds that enter the stratosphere.

\section{Spurr Eruptions in 1992}

The three 1992 Spurr eruptions were subplinian, andesitic, and explosive events that resulted in significant fall deposits and limited pyroclastic avalanches and lahars. Table 1 lists characteristics of these events. They are similar in intensity, dura- tion, magma composition, and volume; however, meteorological conditions differed. Each eruption penetrated the stratosphere at least at the peak of the eruption. Each of the eruptions was recorded by a network of seismic stations (Power et al. 1995) and was observed by C-band radar at Kenai $180 \mathrm{~km}$ SE of Crater Peak; Rose et al. 1995b). The volcano is located near a regular rawindsonde measurement point (Ted Stevens Anchorage International Airport, $125 \mathrm{~km} \mathrm{ESE),} \mathrm{and} \mathrm{the} \mathrm{fall} \mathrm{deposit} \mathrm{from} \mathrm{each}$ event was mapped and sampled (Neal et al. 1995; McGimsey et al. 2001). The Spurr events are typical of worldwide Volcanic Explosivity Index (VEI) = 3 events that occur on the average once per year,

Table 2. Satellite Remote-Sensing Tools Used in Study of Volcanic Clouds

\begin{tabular}{llll}
\hline & \multicolumn{1}{c}{ TOMS } & \multicolumn{1}{c}{ AVHRR } & \multicolumn{1}{c}{ GOES } \\
\hline Wavelengths & $312-380 \mathrm{~nm}$ & $10-12.5 \mu \mathrm{m}$ & $10-12.5 \mu \mathrm{m}$ \\
Orbit & Polar & Polar & Geostationary \\
Sensing target & $\mathrm{SO}_{2}(+\mathrm{ash})$ & Silicate ash & Silicate ash \\
Archive & $1978-$ & $1981-$ & $1996-$ \\
Scenes per day & 1 & $4-8$ & 48 \\
\hline
\end{tabular}


Table 3. Retrieval Data from Volcanic Cloud Sensors, 1999

\begin{tabular}{lccc}
\hline Sensor & Retrieval data & Resolution (at nadir) & Reference \\
\hline TOMS & 2D position, $\mathrm{SO}_{2}$ mass & $50 \mathrm{~km}$ & Krueger et al. 1995 \\
TOMS AI & 2D position, OD (UV) & $50 \mathrm{~km}$ & Krotkov et al. 1999 \\
AVHRR and GOES & 2D position, OD (IR) & $\sim 4 \mathrm{~km}$ & Wen and Rose 1994
\end{tabular}

Note. References give details on the retrieval algorithms. OD (optical depth) is a unitless index of the attenuation of radiation as it passes through the atmosphere due to the presence of suspended particles. OD and turbidity are essentially synonymous quantities, both being logarithmic indices of atmospheric optical attenuation to a vertical beam. OD is highly dependent on wavelength and varies from $<0.1$ (clean atmosphere) to 4 (essentially opaque).

${ }^{a}$ Particle effective radius, mass in $1-15-\mu \mathrm{m}$ range.

which represent the most common type of volcano/ stratosphere interactions, even though some VEI $=3$ events (especially between $30^{\circ} \mathrm{N}$ and $30^{\circ} \mathrm{S}$ latitude) do not actually reach the stratosphere and many have only marginal stratospheric interaction.

\section{Satellite-Sensing Data}

Direct sampling of volcanic clouds by any means remains a difficult task given their well-known hazards (Casadevall 1994). Because of this, study of volcanic clouds has mainly been through remote sensing, using ground-based and satellite sensors. Remote-sensing methods use radar, microwave, infrared (IR), and ultraviolet (UV) multispectral methods that can detect, map, and retrieve spatial information about volcanic clouds. Table 2 lists the main satellite-based techniques used in this study. We also used ground-based C-band radar data that detected the volcanic clouds in their very early stages (until about $30 \mathrm{~min}$ after eruption), while they still contained coarse particles $(2-20 \mathrm{~mm})$ and mass concentrations ranging from $<.01$ to $1 \mathrm{~g} / \mathrm{m}^{3}$ that produce strong radar reflections (Rose et al. $1995 b$ ).

Each of the three Spurr eruptions was observed and measured for several days by both the TOMS and AVHRR satellite detectors, and information about the clouds was retrieved from remote-sensing algorithms (table 3). In this study, we consider and compare basic information about these satellitebased measurements for the three Spurr events (AVHRR data is in tables 4-6; TOMS data from Bluth et al. 1995).

Sequential TOMS and AVHRR data allow us to examine the dynamics of the Spurr volcanic clouds. Figure 1 shows how the two-dimensional area from the satellite perspective changed for the three events. Both TOMS and AVHRR detected volcanic clouds of similar size and followed similar tracks. Separation of the $\mathrm{SO}_{2}$ and ash in the cloud, as noted in other eruptions (e.g., Schneider et al. 1999), did not occur in any of the Spurr eruptions. In all three cases, the area of the clouds increased rapidly at first, and after about 1-2 d, the June and August clouds began to decrease in size. Study of the trajectory of air parcels in conjunction with the satellite data for the June eruption for the first several days after eruption (Shannon 1996) showed that areal growth of the cloud during its first few days was partly due to wind shear, while area decreases that occur after several days are largely the result of loss of the lower-elevation portions of the volcanic clouds.

Table 4. AVHRR Two-Band Brightness Temperature Difference Retrieval Data from the June 1992 Spurr Eruption

\begin{tabular}{lccccr}
\hline $\begin{array}{l}\text { Residence } \\
(\mathrm{h})\end{array}$ & $\begin{array}{c}\text { Effective radius } \\
(\mu \mathrm{m})\end{array}$ & $\begin{array}{c}\text { Optical } \\
\text { depth }\end{array}$ & $\begin{array}{c}\text { Ash mass } \\
(\mathrm{kT})\end{array}$ & $\begin{array}{c}\text { Area } \\
\left(\mathrm{km}^{2}\right)\end{array}$ & $\begin{array}{c}\text { Ash burden } \\
\left(\mathrm{t} / \mathrm{km}^{2}\right)\end{array}$ \\
\hline 4.3 & 8.3 & 1.9 & 317 & 15,000 & 20.80 \\
12.5 & 8.2 & .86 & 438 & 47,000 & 9.24 \\
23 & 6 & .19 & 258 & 167,000 & 1.55 \\
26.3 & 6 & .13 & 194 & 140,000 & 1.38 \\
31.3 & 5 & .16 & 166 & 120,000 & 1.38 \\
36.3 & 6 & .03 & 214 & 134,000 & 1.24 \\
107 & .16 & 183 & 205,000 & .60 \\
118 & 6.5 & .07 & 122 & 137,000 & .93 \\
128 & 5.7 & .1 & 128 & 114,000 & .90 \\
142 & .1 & 102 & 121,000 & .78 \\
146.3 & 6.8 & .09 & 94 & 134,000 & .82 \\
152 & 6.5 & .1 & 110 & & \\
\hline
\end{tabular}

Source. Shannon 1996.

Note. Residence refers to the time passed following the onset of the eruption in hours. Effective radius is given in $\mu \mathrm{m}=1 \times$ $10^{-6} \mathrm{~m}$. Optical depth is a unitless measure of optical thickness. Ash mass is in $\mathrm{kT}=1 \times 10^{9} \mathrm{~g}_{\text {; }}$ ash burden is in metric tons $\mathrm{km}^{2}$. 

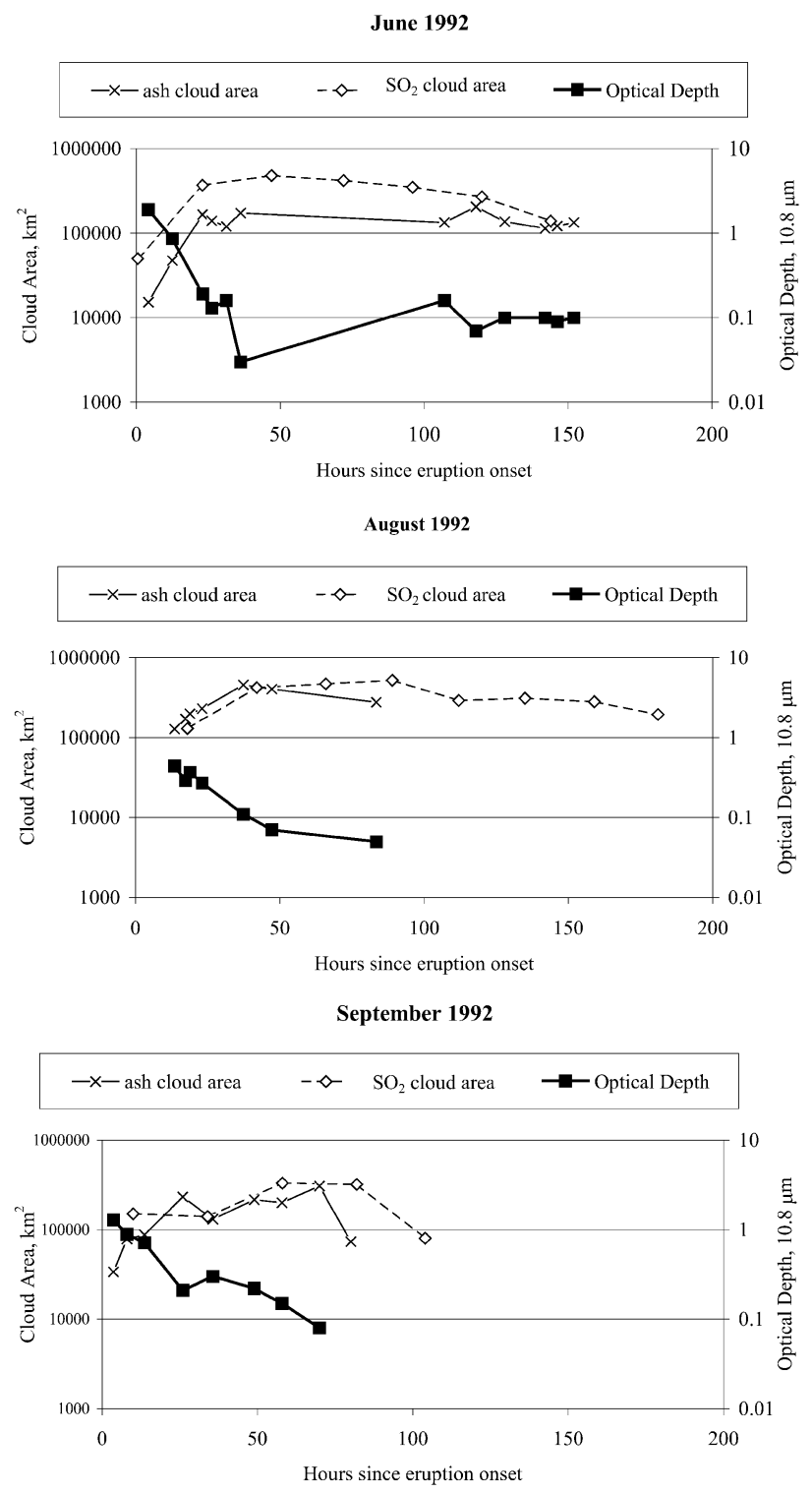

Figure 1. Two-dimensional areas for Spurr clouds and infrared $(10.8 \mu \mathrm{m})$ optical depths for volcanic clouds from the three Spurr eruptions for the first several days after eruption. Areas shown are based on both TOMS $\left(\mathrm{SO}_{2}\right.$ detection) and AVHRR (fine-ash detection) satellite data. Data from tables 4-6.

Estimates of the masses of $\mathrm{SO}_{2}$ and fine (diameters $1-25 \mu \mathrm{m})$ silicate particles in the Spurr volcanic clouds are shown in figure $2 . \mathrm{SO}_{2}$ masses are higher in the second day of measurement for all three of the Spurr events. This difference cannot be explained by the continuing emission of $\mathrm{SO}_{2}$ because the first day's measurement occurred after the end of the eruption (with the exception of the June eruption by about $30 \mathrm{~min})$. It is unlikely to reflect an error in TOMS data analysis (Krueger et al. 1995) that would be far less than the observed difference. It is unlikely that the TOMS detector was saturated or suppressed by an interference from volcanic ash in the $\mathrm{SO}_{2}$ signal because simulations of this effect would likely result in an overestimate the first day rather than an underestimate (Krueger et al. 1995). The favored explanation is that the
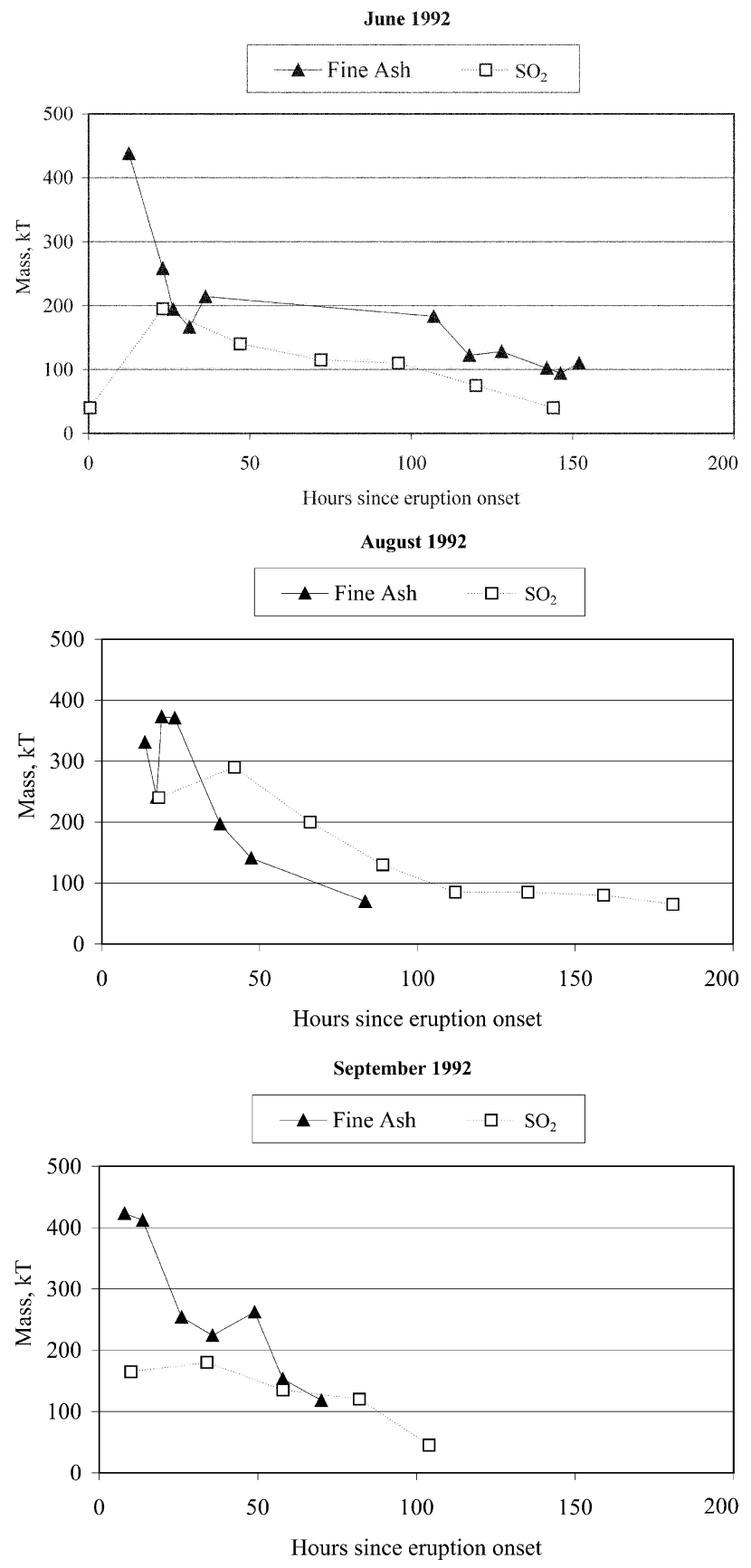

Figure 2. Masses of $\mathrm{SO}_{2}$ and fine ash (1-25 $\mu$ m diameter) in Spurr volcanic clouds. Data from tables 4-6. 

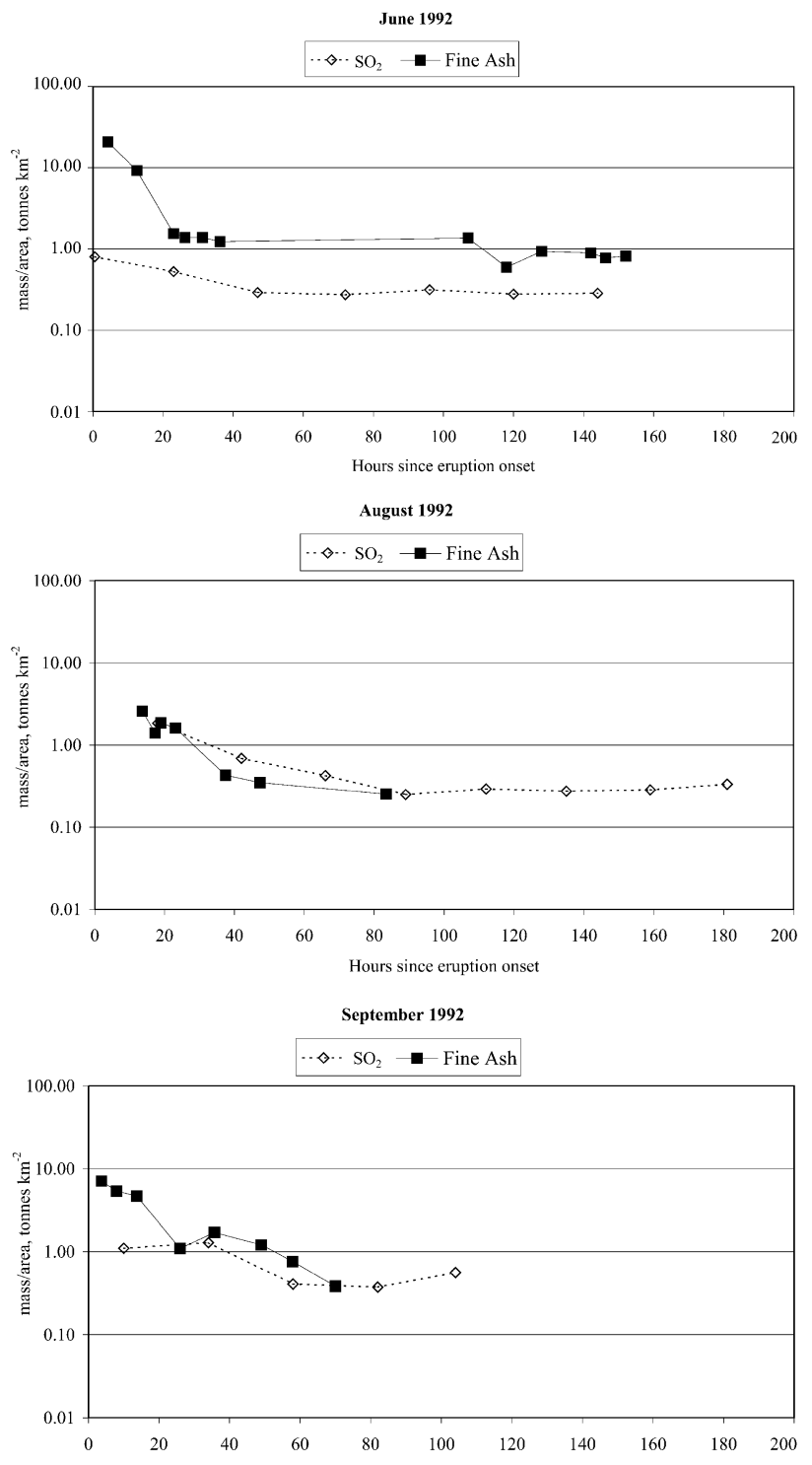

Figure 3. Ash burdens of 1992 Spurr volcanic clouds. Data from tables 4-6. mass increase is due to coemission and subsequent oxidation of $\mathrm{H}_{2} \mathrm{~S}$ (Rose et al. 2000), but we are also investigating the possibility of temporary sequestration of $\mathrm{SO}_{2}$ by ice during the first day followed by subsequent release during the fallout and desiccation of ashy hydrometeors (see "Discussion").

The maximum fine-ash masses detected in the Spurr volcanic clouds represent about $2 \%$ of the estimated total mass erupted in each eruption (table 7), a fraction that is up to two orders of magnitude higher than was found for several larger eruptions. We interpret this difference as reflecting the greater efficiency of ash removal for more intense eruptions as a result of higher rates of particle reentrainment into the eruption column and more efficient removal by aggregation as predicted by Ernst et al. (1996). By analogy with the work of Pinto et al. (1989) on sulfate aerosol, one complementary explanation may be that ash aggregation processes are also enhanced when there are highermass fluxes/concentrations of particles in the ash cloud. The fine-ash masses (fig. 2) decline at a more rapid rate during the first day of residence and at a slower rate nearly parallel to the $\mathrm{SO}_{2}$

A measure of the area-averaged "burden" of the volcanic clouds can be estimated by dividing masses by areas in tables 4-6 (fig. 3). The ash burdens for all three eruptions decline very rapidly in the first day, and quite slowly thereafter, while $\mathrm{SO}_{2}$ burdens show slow declines after the second day. The ash-burden estimates correlate well with optical depths (fig. 4) as would be expected.

Effective radius is a ratio of volume to area (related to particle size) that is retrieved for particles from IR remote sensing (table 5). These data show that the June volcanic cloud had higher effectiveradius values (fig. 5). We are unsure of the detailed meaning of these results. Higher effective-radius values for the June case could reflect the greater influence of ice (see Rose et al. 2000 for more discussion of the role of ice and Doukas and Gerlach 1995 for description of wetter conditions in June).

Table 5. AVHRR Two-Band Brightness Temperature Difference Retrieval Data from the August 1992 Spurr Eruption

\begin{tabular}{lccccc}
\hline $\begin{array}{l}\text { Residence } \\
(\mathrm{h})\end{array}$ & $\begin{array}{c}\text { Effective radius } \\
(\mu \mathrm{m})\end{array}$ & $\begin{array}{c}\text { Optical } \\
\text { depth }\end{array}$ & $\begin{array}{c}\text { Ash mass } \\
(\mathrm{kT})\end{array}$ & $\begin{array}{c}\text { Area } \\
\left(\mathrm{km}^{2}\right)\end{array}$ & $\begin{array}{c}\text { Ash burden } \\
\left(\mathrm{t} / \mathrm{km}^{2}\right)\end{array}$ \\
\hline 13.6 & 4.44 & .44 & 331 & 128,000 & 2.59 \\
17.3 & 3.44 & .29 & 241 & 171,000 & 1.41 \\
18.9 & 3.61 & .37 & 373 & 199,000 & 1.87 \\
23.1 & 4.41 & .27 & 371 & 230,000 & 1.61 \\
37.4 & 2.21 & .11 & 197 & 455,000 & .43 \\
47.3 & 1.65 & .07 & 141 & 403,000 & .35 \\
83.4 & 2.61 & .05 & 70 & 276,000 & .25 \\
\hline
\end{tabular}

Source. Schneider et al. 1995. 
Except for the higher June values, the effective radius for all three Spurr events otherwise displays a qualitatively similar evolution with time consisting of decreasing size. This decrease was also observed in data from El Chichón volcano (Schneider et al. 1999, fig. 4, p. 4048). There are apparent minima in all three curves at $\sim 36, \sim 50$, and $\sim 24 \mathrm{~h}$, but we hesitate to interpret much from these at this point because effective-radius retrieval is imprecise and is known to be affected by atmospheric water vapor (Yu et al. 2002).

\section{Stages of Volcanic Cloud Evolution}

The Spurr clouds seem to have three stages of evolution (table 8). First, during the eruption and for $1-2 \mathrm{~h}$ following, they grow rapidly in area and are essentially optically opaque to the IR sensor. At this stage, they resemble thunderstorms and typically exhibit very cold temperatures to the IR sensors. The core of these clouds is opaque in the IR (optical depth $\sim 4$ ), and we cannot retrieve size and mass information (fig. 6). During the first $30 \mathrm{~min}$ after the eruption stops, the C-band radar signal (proportional to the sixth power of the particle radius) falls rapidly as all coarse ash and lapilli-sized ejecta fall out from the ash cloud at high Re (Bonadonna et al. 1998), accounting for much (>70\%) of the total volume of fall materials. This material falls out (deposit mass/area $=10,000-250,000$ $\mathrm{g} / \mathrm{m}^{2}$ ) in the proximal ash blanket covering an area of about $300 \mathrm{~km}^{2}$ (approximately the area outlined by the isomass lines surrounding Mount Spurr in fig. 7).

In the second stage of volcanic cloud evolution that lasts no more than about one day, the cloud continues to grow aerially, increasing its area by a factor of two to five (fig. 1), but its optical depth and fine-particle concentration decreases very rapidly by an order of magnitude or more. This period correlates with the time of premature fallout of aggregated fine ash in a settling regime characterized

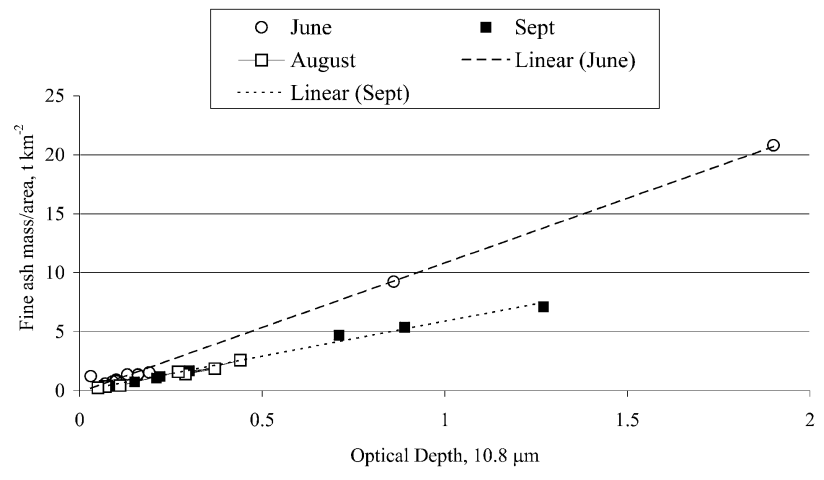

Figure 4. Plots of linear covariations between optical depth and ash burden. Data from tables 4-6.

by particle Re number transitional between laminar and turbulent (Riley et al. 1999) and the formation of a secondary-fallout maximum that is well defined for both the August and September Spurr events (fig. 7; McGimsey et al. 2001). The deposit mass/area of fallout $\left(100-2500 \mathrm{~g} / \mathrm{m}^{2}\right)$ is much less and the area of fallout $\left(\sim 5 \times 10^{4} \mathrm{~km}^{2}\right)$ much greater for this secondary-fallout maximum compared to the primary-fallout maximum that is located adjacent to the volcano. The rapid reduction of mass of fine particles in the cloud during this period (fig. 2) likely reflects an aggregation process because the terminal velocities of fine $(<20 \mu \mathrm{m})$ particles are far too slow for them to fall from tropopause heights in only one day unless they are part of much larger aggregates. The mapped fallout of the August and September Spurr events all lie under regions that the volcanic clouds passed over within the first $15 \mathrm{~h}$ after the eruption. Also, during this second stage, the $\mathrm{SO}_{2}$ masses in these clouds increase, possibly reflecting the rapid conversion of $\mathrm{H}_{2} \mathrm{~S}$ to $\mathrm{SO}_{2}$ (Bluth et al. 1997).

A third stage in volcanic cloud evolution lasts for several (3-5) days, during which the cloud moves thousands of kilometers, its ash concentra-

Table 6. AVHRR Two-Band Brightness Temperature Difference Retrieval Data from the September 1992 Spurr Eruption

\begin{tabular}{lccccc}
\hline $\begin{array}{l}\text { Residence } \\
(\mathrm{h})\end{array}$ & $\begin{array}{c}\text { Effective radius } \\
(\mu \mathrm{m})\end{array}$ & $\begin{array}{c}\text { Optical } \\
\text { depth }\end{array}$ & $\begin{array}{c}\text { Ash mass } \\
(\mathrm{kT})\end{array}$ & $\begin{array}{c}\text { Area } \\
\left(\mathrm{km}^{2}\right)\end{array}$ & $\begin{array}{c}\text { Ash burden } \\
\left(\mathrm{t} / \mathrm{km}^{2}\right)\end{array}$ \\
\hline 3.7 & 2.99 & 1.27 & 240 & 34,000 & 7.13 \\
8 & 4.43 & .89 & 423 & 79,000 & 5.39 \\
13.7 & 5.07 & .71 & 412 & 87,000 & 4.71 \\
26 & 3.23 & .21 & 254 & 232,000 & 1.09 \\
35.7 & 3.88 & .3 & 224 & 131,000 & 1.71 \\
49 & 3.89 & .22 & 262 & 216,000 & .76 \\
57.9 & 3.23 & .15 & 153 & 200,000 & .76 \\
70 & 2.2 & .08 & 118 & 307,000 & .38 \\
\hline
\end{tabular}

Source. Schneider et al. 1995. 
tions and optical depths decrease very slowly, and the masses of both $\mathrm{SO}_{2}$ and fine particles decrease steadily. During this stage, fallout is very light and at low Re (Bonadonna et al. 1998), and the mass of remaining fine silicate particles is only at most a few percent of the total erupted volume. Finally, after several days, both the IR and UV detection of the cloud become difficult because the concentrations of $\mathrm{SO}_{2}$ and ash fall below the level of noise. Except for the June volcanic cloud that traversed very cold Arctic regions that limited the sensitivity of the IR detector from about 20-120 h after the eruption, the positions, shapes, and sizes of the $\mathrm{SO}_{2}$ and silicate-ash volcanic clouds were very similar throughout. This suggests that the $\mathrm{SO}_{2}$ and ash moved as part of the same air parcels.

Factors Controlling Cloud-Shape Evolution. For the August 18, 1992, Spurr event, we use a photograph of the volcanic cloud from a fixed-wing airplane (fig. 7 in Neal et al. 1995) and three satellite images from band 4 data (at 0126, 0331, and 0512 GMT [fig. 6]) to analyze volcanic cloud dispersal during stage 1 and the first part of stage 2 when aircraft ash-related hazards are highest. In stage 1, figure 8 ashows data for the cloud front (distance to the upwind leading edge) as a function of time. There is a short initial period, $<15 \mathrm{~min}$ in duration, when downwind spreading is enhanced by radial gravity flow. After this, the data are consistent with downwind spreading by simple advection by uppertropospheric winds of ca. $20 \mathrm{~m} / \mathrm{s}$. This is consistent with wind data of $\sim 6-12 \mathrm{~km}$ asl (table 1).

Figure $8 c$ shows data for the maximum volcanic cloud width against downwind distance measured as in figure $8 a$. We compare the data with the theoretical prediction assuming that lateral spreading is controlled by intrusive gravity current flow, while the cloud is being advected downwind (Bursik et al. 1992; Sparks et al. 1997). The theory neglects wind shear as a first approximation. It further assumes a volcanic cloud steadily supplied from below by the eruption column, with no entrain-

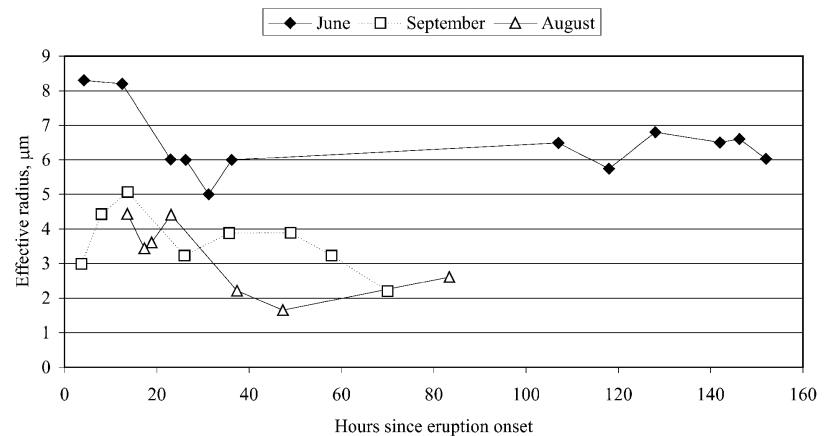

Figure 5. Effective radius of silicates in Spurr volcanic clouds. Data from tables 4-6.

ment into the cloud and negligible lateral spreading due to diffusion from atmospheric turbulence. The theoretical expectation that also compared well with data for the May 18, 1980, Mount St. Helens cloud (see fig. $8 b, 8 d$ ) is that maximum cloud width (y[max $])$ scales as the square root of distance to the cloud front $(x)$ :

$$
y(\max )=U^{-1} \sqrt{2 \lambda N Q x}
$$

where $U$ is the windspeed at the cloud height (in $\mathrm{m} / \mathrm{s}), \lambda$ is a parameter $(\sim 1)$ that depends on flow geometry, $N$ is the Brunt-Vaïsälä frequency of the atmosphere $(\sim 0.035 s-1$; a measure of its density stratification), and $Q$ is the volumetric flux of material, assumed constant, in the steady advected volcanic cloud and related to column height $(\mathrm{Ht})$ using $Q=([\mathrm{Ht} \text { in } \mathrm{km}] / 0.287)^{5.3}$. Thus, the expectation is of a near-parabolic, cloud-shape profile that is in agreement with Mount St. Helens data as well as with Spurr data from the upwind edge to the location where maximum lateral spreading is observed.

The assumption of constant flux at the vent is only robust to a first order, so we conclude that the agreement between theory and data is satisfactory

Table 7. Fine-Ash Masses Measured in Volcanic Clouds by Satellite

\begin{tabular}{lcccc}
\hline Volcano & Date & Total mass erupted $^{\mathrm{a}}$ & Maximum fine ash detected & Percentage $^{\mathrm{a}}$ \\
\hline Spurr & $6 / 92$ & $21.1^{\mathrm{b}}$ & .44 & 2.1 \\
Spurr & $8 / 92$ & $21.3^{\mathrm{b}}$ & .42 & 2.0 \\
Spurr & $9 / 92$ & $23.3^{\mathrm{b}}$ & .61 & 2.6 \\
El Chichón & $4 / 82$ & $910^{\mathrm{c}}$ & $6.5^{\mathrm{c}}$ & .7 \\
Láscar & $4 / 93$ & $345^{\mathrm{d}}$ & $4.8^{\mathrm{e}}$ & 1.4 \\
Hudson & $8 / 91$ & $7600^{\mathrm{f}}$ & $2.9^{\mathrm{g}}$ & .04 \\
\hline
\end{tabular}

Source. Rose et al. 2000.

Note. Effective radius $=1-12 \mu \mathrm{m}$. Letters in superscript in table body refer to the following sources: ${ }^{\mathrm{b}} \mathrm{Neal}$ et al. 1995; ${ }^{\mathrm{c} S c h n e i d e r}$

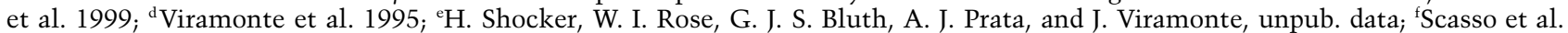
1994; ${ }^{\mathrm{g}}$ Constantine et al. 2000.

${ }^{a}$ Reported in metric tons $\left(1 \times 10^{6} \mathrm{~g}\right)$. 

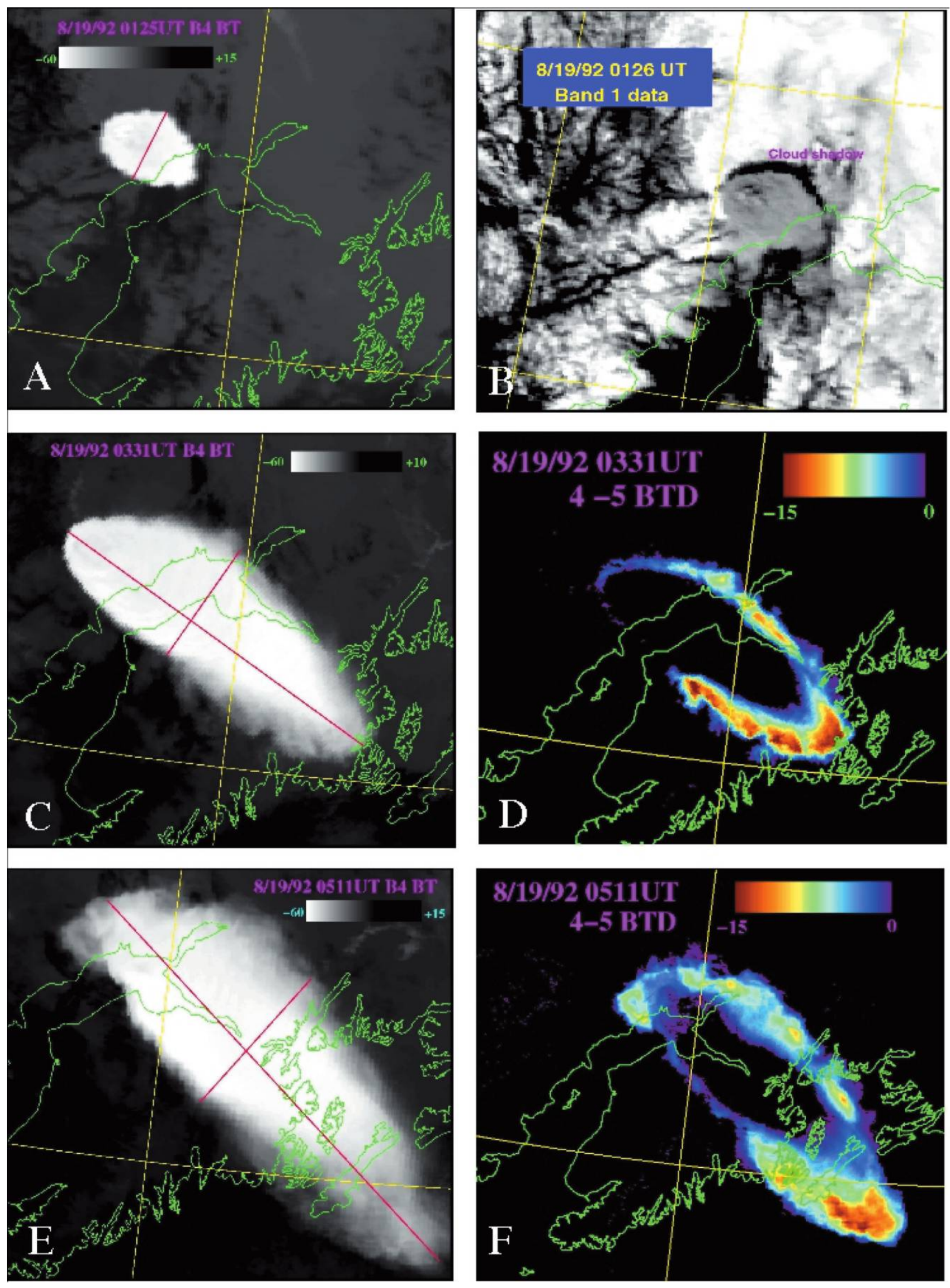

This content downloaded from 141.219.044.085 on March 12, 2018 11:39:16 AM

All use subject to University of Chicago Press Terms and Conditions (http://www.journals.uchicago.edu/t-and-c). 
Table 8. Stages Defined in Volcanic Cloud History based on Spurr Volcanic Clouds

\begin{tabular}{llll}
\hline & 1 & 2 & 3 \\
\hline Duration (h after eruption stops) & $\sim 1-2$ & $18-24$ & $24-96+$ \\
Fallout (km from volcano) & $<25$ & $25-400$ & $>400$ \\
Area of fallout $\left(\mathrm{km}^{2}\right)$ & $<300$ & $\sim 5 \times 104$ & ?, discontinuous \\
Fallout diameter range $(\mathrm{mm})$ & $>.5$ & $.5-<.01$ & $<.01$ \\
Fallout rate $(\mathrm{kT} / \mathrm{h})$ & $>10^{4}$ & $<10^{4}-10^{2}$ & "very" low \\
Fraction of fine ash $([$ diameter $1-25 \mu \mathrm{m}] \%)$ & $<1$ & $10-50$ & $>50$ \\
Cloud area $\left(\mathrm{km}^{2}\right)$ & $<10^{4}$ & $10^{4}-10^{6}$ & $10^{6}$, decreasing \\
Cloud area change $(\% / \mathrm{h})$ & $>100$ & $30-50$ & -10 to + \\
Mean optical depth $(11 \mu \mathrm{m})$ & $>2$ & $.5-2$ & $<.3$ \\
Cloud ash burden $\left(\mathrm{T} / \mathrm{km}^{2}\right)$ & $>25$ & $3-10$ & $<3$ \\
Fraction of ash mass suspended $(\%)$ & $100-\sim 30$ & $\sim 30-3$ & $<3$ \\
\hline
\end{tabular}

(see fig. 8e). In particular, accounting for diffusion by atmospheric turbulence is not essential for anticipating maximum cloud spreading because it would not significantly improve the comparison. In summary, data for stage 1 and early stage 2 cloud maximum spreading are consistent with an advected gravity current that is unaffected by diffusion or wind shear. Diffusion and wind shear may however exert at least a partial control on the cloud-shape profile beyond the location of maximum spreading. When these two effects are unimportant, the expectation is that maximum cloud spreading is observed near the leading downwind edge of the cloud (May 18, 1980, Mount St. Helens case; Bursik et al. 1992); however, where wind shear/diffusion are important, maximum spreading is expected to occur at a considerable distance farther upwind than the leading edge (August Spurr case).

The spreading behavior of the August Spurr cloud shares many similarities with the May 18, 1980, Mount St. Helens cloud that also interacted mostly with upper-tropospheric winds $(30 \mathrm{~m} / \mathrm{s}$ in the Mount St. Helens case; fig. $8 b, 8 d, 8 f)$. The figures together constrain key aspects of the geometry of a spreading cloud: upwind leading edge, maximum volcanic cloud lateral extent, and distance from the vent to the cloud front.

During the first part of stage 2, most of the cloud is still growing as a gravity current. During the rest of stage 2 , the cloud continues to grow due to a combination of wind shear, cloud edge diffusion, and downwind advection so the cloud shape becomes more complex. In particular, the volcanic ash cloud may become apparently segmented as documented by Schneider et al. (1995) for the August Spurr cloud. During stage 3, the drifting cloud is dynamically weakest, and it becomes discontinuous and diffuse (case of the August 1992 Spurr; see fig. 3 of Schneider et al. 1995) unless it is rapidly entrained and concentrated around mesoscale meteorological eddies (case of September Spurr cloud). Cloud shape is less complex than in stage 2 in the case where the cloud is drawn out, stretched, and bent around a large mesoscale eddy (see fig. 4 in Schneider et al. 1995). A similar evolution during stage 3 was documented by Constantine et al. (2000) for the August 1991 Hudson volcanic cloud, which was observed to be drawn out, stretched, and bent around the Antarctic polar vortex in the lower stratosphere. In these latter cases, the volcanic clouds appeared to slowly increase in total size, and cloud width was much less than in stage 1 or 2 .

\section{Relationship of Cloud Evolution to Tephra Deposition}

The ash fallout from all three eruptions was sampled and mapped by McGimsey et al. (2001; fig. 7). The June deposit was mapped and sampled in a more limited way (the map is undefined to the north), while the August and September deposits were followed for distances of up to $1000 \mathrm{~km}$. The latter two events show a clearly defined secondary

Figure 6. AVHRR images at $0125(A, B), 0331(C, D)$, and $0511 \mathrm{GMT}(E, F)$ on August 19, 1992, during and immediately following the eruption of August 19, 1992. A, C, E, Band 4 brightness temperature images that show the expanding, thunderstorm-like cold image of the volcanic cloud. $B$, A visible (band 1) image showing the dark color of the stage 1 ash cloud and its prominent shadow. D, F, Band 4-band 5 brightness temperature difference images in which the opaque (optical depth $\sim 4$ ) core of the cloud shows no signal but the transparent fringe is brightly outlined. These stage 1 volcanic clouds have opaque cores with optical depths of 4 or more, preventing retrievals of the entire cloud. See Schneider et al. 1995. 


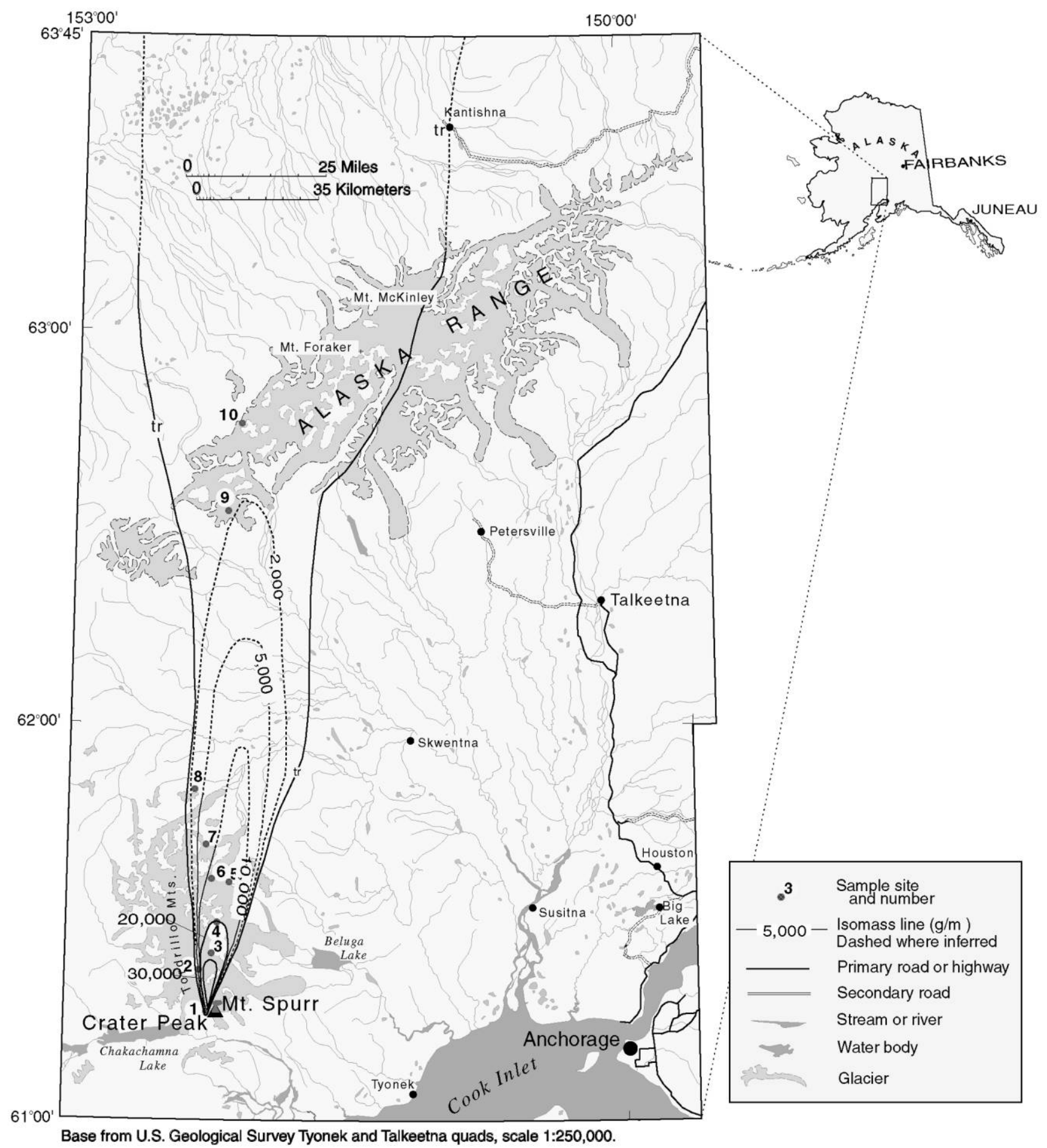

Figure 7A

Figure 7. $A-C$, Fallout maps of the three 1992 eruptions (McGimsey et al. 2001). The location of the Wells Bay fallout sample from the August blanket is marked by 44 in $B$.

maximum in mass/area of fall deposits located within the broad fallout zone outlined downwind. Size and shape determinations of distal Spurr fallout materials were made by Riley et al. (1999). Sev- eral of the authors also independently modeled the dispersal data using trajectory models for single ash particles and aggregates of different sizes/porosities/densities falling from a 10-14-km-high vol- 


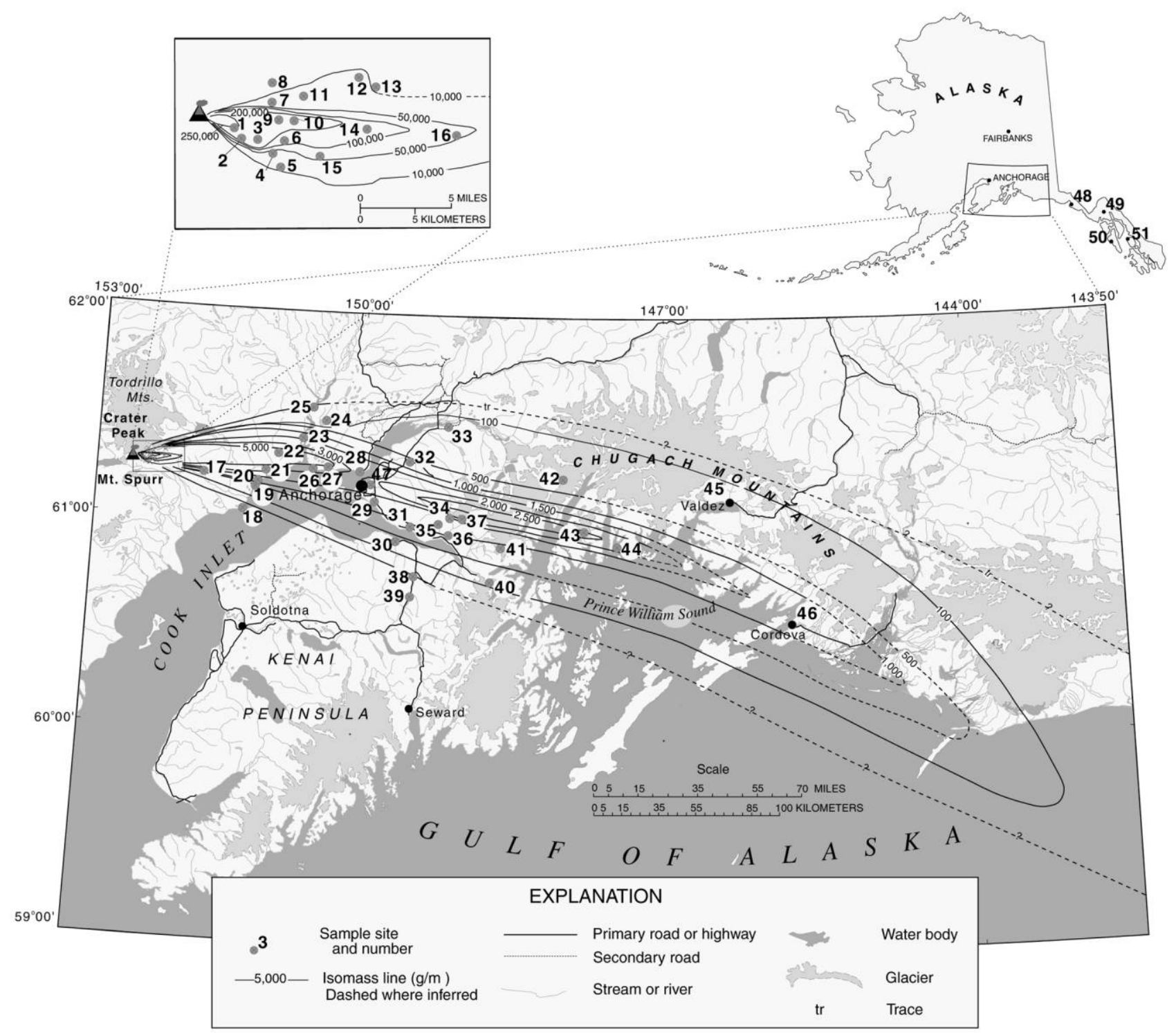

Figure $7 B$

canic cloud. The cloud outlines during stage 1 (and very early during stage 2) in figure 6 correspond with the region of isomass contours of $5000 \mathrm{~g} / \mathrm{m}^{3}$ in figure $7 B$, which roughly defines the stage 1 deposit region and within which a first maximum of mass accumulation is observed. We suggest that these regions reflect fallout mainly as single separate particles. The conclusion from these dispersal modeling studies is that the bimodal fallout materials (fig. 9) of the secondary-maxima regions fell as aggregates of fine ash that had diameters of 100-300 $\mu \mathrm{m}$ but contained a large majority of much finer particles, most in the $10-30 \mu \mathrm{m}$ range. A size distribution of one distal Spurr ash sample that fell at Wells Bay (44 in fig. $7 B$ ) is shown in figure 9. It is bimodal with peaks at about $18 \mu \mathrm{m}$ and $90 \mu \mathrm{m}$. Two modes with similar values were documented from equivalent locations relative to the secondary maximum for other medial deposits (e.g., Mount St. Helens, May 18, 1980; Carey and Sigurdsson 1982), and the larger mode of the deposits were thought to reflect fallout of single particles, while the smaller mode reflected aggregated ones that fell prematurely. C. M. Riley (unpub. data) measured the terminal velocities of the individual particles in the Wells Bay sample and concluded that these very fine ashfall materials would have fallen out at distances about five to 10 times farther from the 

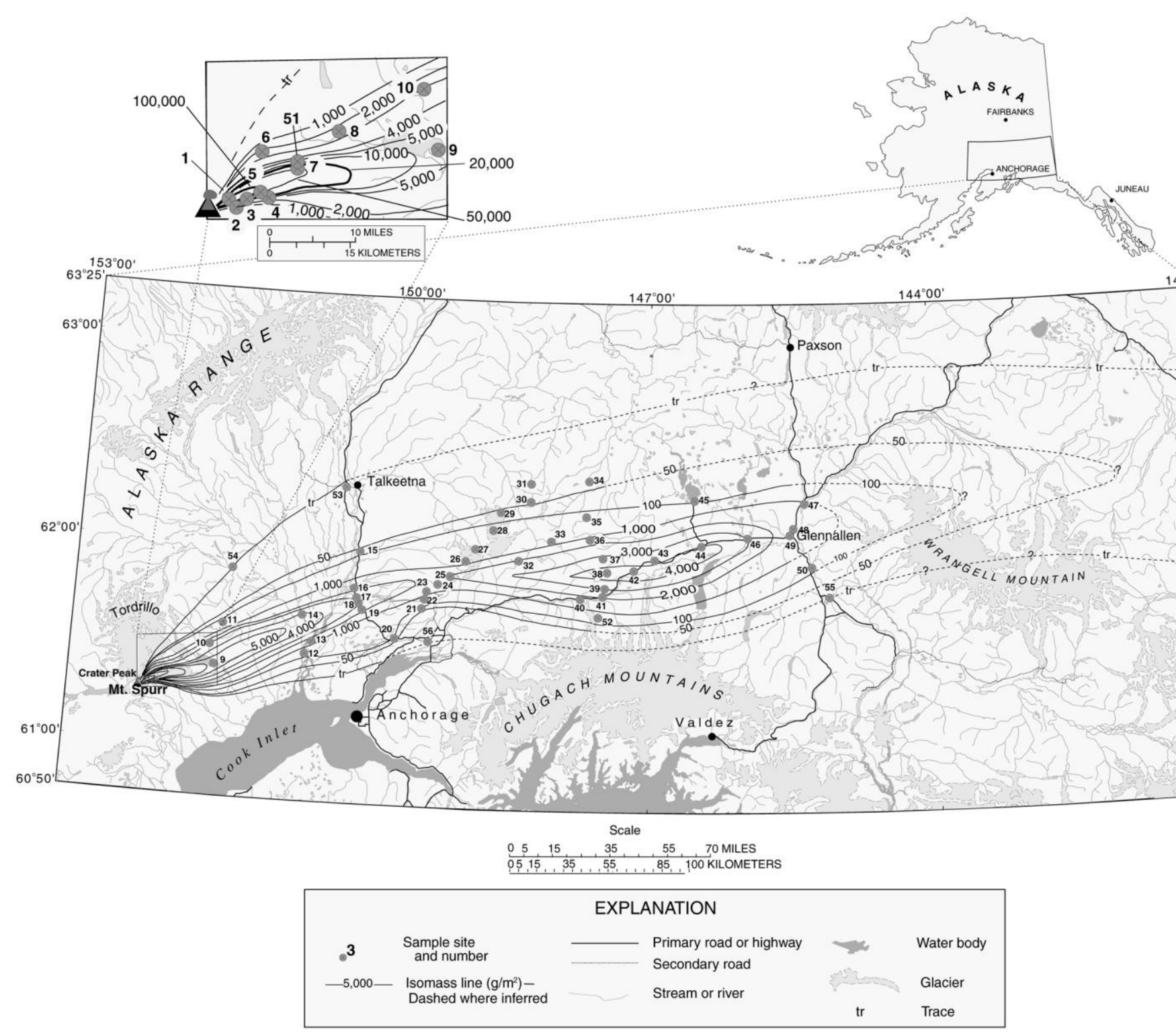

Figure $7 C$

This content downloaded from 141.219.044.085 on March 12, 2018 11:39:16 AM 
volcano if they remained as simple separate particles. The volcanic clouds observed by AVHRR passed over the secondary maximum at times (4-15 $h$ after eruption) that fall squarely in the stage 2 of the volcanic cloud. Consistent with McGimsey et al. (2001), we conclude that the secondary-maxima regions of the latter two Spurr events are closely associated with a period of particle aggregation. Furthermore, based on position and travel times, this aggregation correlates with stage 2 of cloud evolution. It is thus likely that the rapid decreases in particle mass retrieved (tables 4-6), optical depth (fig. 1), and the burden of particles in the volcanic cloud (fig. 3) during stage 2 result from this aggregation process and the resulting mass removal from the cloud.

After the first 18-24 h, Spurr's volcanic clouds drifted along undergoing minimal changes. They either remained about the same in two-dimensional area, optical depth, and ash-particle density or slowly decreased in size (fig. 3). Detailed study of the June cloud by Shannon (1996) showed that that cloud lost area from its more rapidly drifting leading edge. This suggests that meteorological processes can cause the disappearance of volcanic clouds, perhaps because fine ash in their lower parts acts as cloud condensation nuclei. We note that the decreases in $\mathrm{SO}_{2}$ mass during this period are much more rapid (e-folding only a few days) for these tropospheric volcanic clouds than that estimated for long-lived stratospheric clouds (Bluth et al. 1997), which suggests that $\mathrm{SO}_{2}$ may be removed by meteorological processes also.

Bonadonna et al. (1998) suggested that volcanic cloud (i.e., umbrella region) fallout is expected to produce three segments on a $\ln \mathrm{T}$ versus $\mathrm{A}^{1 / 2}$ diagram. These three segments respectively correspond to high, intermediate, and low Re number settling regimes that impose a significant control on ash thickness decay rates away from vent. From this new work, however, it can be anticipated that the effect of aggregation that was not accounted for in modeling by Bonadonna et al. (1998) is likely to reduce the three medial/distal segments to only two segments. This is expected because, at least in the Spurr case, aggregation appears to be highly efficient at removing most of the fine ash (which would otherwise fall at low Re) as larger ash clusters that fall within the intermediate Re regime of settling. The above accounts for the relatively poor match between the proportion of fine (low Re number) ash predicted by Bonadonna et al. (1998) as compared to grainsize data for field deposits such as the 1932 Quizapú and 1991 Hudson (see table 1 in Bonadonna et al. 1998). The Bonadonna et al.
(1998) model systematically overestimates the amount of low-Re ash at any distance compared to field deposits because aggregation is highly efficient at prematurely removing those particles. The number of segments on $\ln \mathrm{T}$ versus $\mathrm{A}^{1 / 2}$ dispersal diagrams also depends on initial grainsize distribution of the material erupted. For example, if the distribution is such that there are no high Reynolds number particles (e.g., phreatomagmatic eruptions), then the expected two segments may end up as only one because of the effect of ash aggregation by the mechanism already suggested. This accounts for the fact that not all plinian medial/ distal deposits display more than one segment even when data coverage appears sufficient (see Pyle 1989).

\section{Discussion}

The Role of Ice in Volcanic Clouds. The $1994 \mathrm{Ra}-$ baul eruption (Rose et al. 1995a) has raised our awareness of the role of hydrometeors (rain, hail, snow, sleet, etc. [especially forms of ice]) in volcanic clouds. Work in the application of eruption column models that includes microphysical processes (Herzog et al. 1998; Textor 1999) has further emphasized the possible role of ice. The source of $\mathrm{H}_{2} \mathrm{O}$ for the formation of hydrometeors comes from the magma and from entrainment (Woods 1993; Glaze et al. 1997) and, in the case of Rabaul and Soufrière Hills (Mayberry et al. 2001), from the ocean. Even though there was no interaction with the ocean, the Spurr volcanic clouds may have also contained ice derived from freezing of the magmatic water vapor, from entrainment of atmospheric moisture, and possibly water from the hydrothermal system or from melting of glacial ice by the magmatic heat. One of the principal roles of the ice could be to accelerate the fallout of fine pyroclasts by enhancing or driving the aggregation. Ice-coated pyroclasts may be more likely to stick to each other than nonicy ones. Once aggregates start to form, they will have a high surface area relative to their mass (specific surface area) and could rapidly fill up with ice by deposition of water vapor and heterogeneous nucleation on the aggregate. In the Spurr case, the dispersal data are consistent with aggregates of $200 \mu \mathrm{m}$ and $60 \%$ porosity (accretionary lapilli-like particles; i.e., with a density of $1025 \mathrm{~kg} / \mathrm{m}^{3}$ ). Alternatively, the data is also consistent with aggregates of 200 microns and $90 \%$ porosity (loosely bound clusters like those described by Sorem [1982] at Mount St. Helens) with all the pore space filled with ice (bulk density of about $1080 \mathrm{~kg} / \mathrm{m}^{3}$ ). Since the bulk density without 

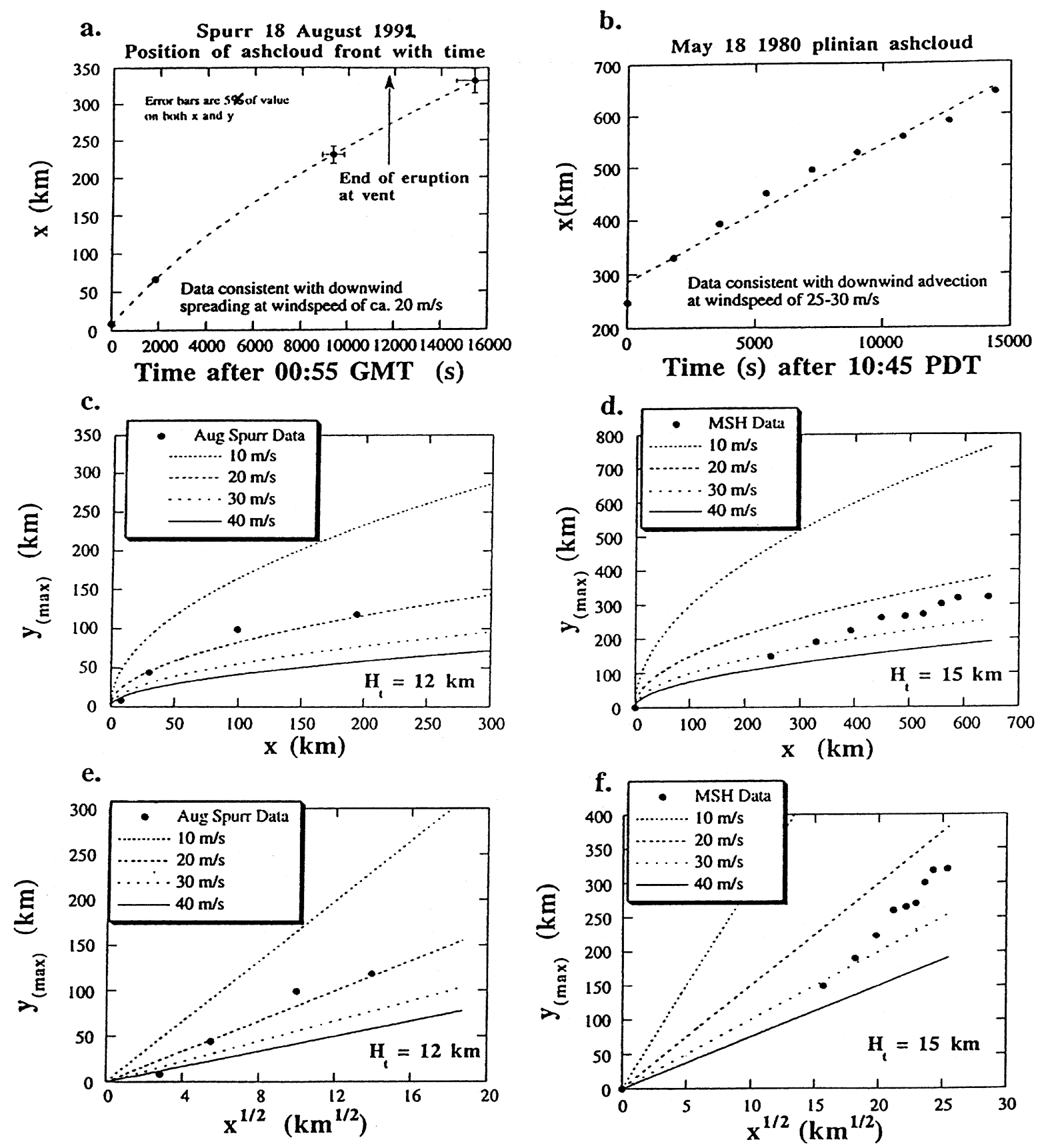

Figure 8. Spreading of upper-tropospheric and lower-stratospheric volcanic clouds (tropopause-straddling clouds) for contrasting crosswinds at mean cloud height. $a$, Position of cloud front $(x)$ versus time after 0055 GMT for the August 19, 1992, Spurr eruption as measured from a photograph showing that the cloud reached height within 13 min of the eruption's onset (Neal et al. 1995) and band 4 satellite imagery (see Schneider et al. 1995 for details on the images). All values of $x$ are measured relative to the position of the upwind leading edge of the cloud. Data are consistent with short-lived radial spreading (for less than ca. $15 \mathrm{~min}$ ) followed by downwind advection at an average windspeed of ca. $20 \mathrm{~m} / \mathrm{s}$. $b$, Maximum crosswind cloud width (y[max]) versus distance to cloud front $(x)$ measured as in $a$ for the August 19, 1992, Spurr eruption. Data are consistent with lateral spreading as an intrusive gravity current while 
ice is only $270 \mathrm{~kg} / \mathrm{m}^{3}$, the role of ice is important to induce premature fallout and control the location of the secondary maximum. If ice is present, it is not present in sufficient amounts to suppress the signal of ash absorption and scattering in the two-band IR remote sensing. Microphysical modeling (Textor 1999) suggests that ice/ash aggregates that have high mass proportions are possible in volcanic clouds if only magmatic and entrainment sources are considered. The proportions of ice would be much less in the Spurr events than for eruptions occurring in moist tropical atmospheres because the component of $\mathrm{H}_{2} \mathrm{O}$ from atmospheric entrainment would be much less. Doukas and Gerlach (1995) note that there was scrubbing of $\mathrm{SO}_{2}$ emissions by glacial melt and/or hydrothermal fluids at Crater Peak before and after the 1992 eruptions, which implies that this source of water may be potentially important. Although no evidence of ice is seen in the fallout materials, the same models suggest that ice would melt and evaporate before deposition. We hope to apply the active tracer highresolution atmospheric model (ATHAM) in detail to the Spurr volcanic clouds to determine whether the Spurr eruptions emplaced in a dry subarctic atmosphere would generate sufficient ice to enhance aggregation.

As explained above, the favored explanation for the increases observed in $\mathrm{SO}_{2}$ mass in the Spurr volcanic clouds is the coeruption of $\mathrm{H}_{2} \mathrm{~S}$ and its conversion after atmospheric emplacement (Rose et al. 2000). There are no direct data supporting this hypothesis, however. An alternative explanation is possible if there could be a sequestration of $\mathrm{SO}_{2}$ in ice within the early volcanic cloud. This hypothesis was invoked by Rose et al. (1995a) to explain the extremely low $\mathrm{SO}_{2}$ mass in the volcanic clouds of Rabaul, a volcano whose vent was at sea level and was readily accessible to seawater. In the case of the Spurr events, most of the $\mathrm{H}_{2} \mathrm{O}$ vapor in the volcanic cloud would have to come from the magma and from entrainment of moist tropospheric air. This may be consistent with the relatively minor suppression of $\mathrm{SO}_{2}(\sim 25 \%)$ and its restriction to the first day. During the fallout of ash in stage 2, ice evaporates and $\mathrm{SO}_{2}$ is released to the atmosphere, which explains the second-day rises. At this point, we offer this possible explanation as a speculation.

Volcanic Cloud Hazard to Aircraft. The rapid decrease in ash mass during stage 2 of volcanic clouds is potentially significant to the issue of volcanic cloud hazards because nearly all seriously damaging aircraft encounters have occurred within $24 \mathrm{~h}$ after activity. The rapid decrease in ash burden (and inferred ash concentration) in stage 2 of volcanic clouds (fig. 3) suggests that the processes accelerating the fallout of fine ash are efficient enough to

downwind advection at the windspeed is occurring. Data are also consistent with a steadily fed, 12-km-high cloud of roughly constant volumetric flux with little apparent role for atmospheric diffusion or wind shear. Theoretical predictions for different windspeeds at cloud height $(\mathrm{Ht}=12 \mathrm{~km})$ are also shown for comparison with the data. $c$, Position of cloud front $(x)$ versus time after 1045 PDT for the May 18, 1980, Mount St. Helens plinian cloud (see Bursik et al. 1992 and Sparks et al. 1997 for a more detailed analysis of the Mount St. Helens cloud dynamics) for comparison with $a$. Mount St. Helens data has been remeasured from figure 332 in Sarna-Wojcicki et al. (1981). In contrast with $a$, all values of $x$ are measured relative to vent position (but this makes little difference to analysis). Data are also consistent with downwind advection at the local windspeed at cloud height, about 25-30 m/s. $d$, Maximum crosswind cloud width (y[max]; measured as projection to N-S direction) versus distance (measured as projection to E-W direction) to cloud front, measured as in $b$ for the May 18, 1980, plinian cloud. Data are consistent with lateral spreading as an intrusive gravity current while downwind advection at the windspeed is occurring. Data are also consistent with a steadily fed, 15-km-high cloud of roughly constant volumetric flux with little role for atmospheric diffusion or wind shear. Theoretical predictions for different windspeeds at cloud height $(\mathrm{Ht}=15 \mathrm{~km})$ are also shown for comparison with the data. $e$, Maximum crosswind cloud width (y[max]) versus square root of distance to cloud front (measured as in $a$ ) for the August 19, 1992, Spurr eruption. Data are consistent to a first order with lateral spreading as an intrusive gravity current while downwind advection at the windspeed is occurring. Data are also consistent with a steadily fed, 12-km-high cloud of roughly constant volumetric flux with little role for atmospheric diffusion or wind shear. Theoretical predictions for different windspeeds at cloud height $(\mathrm{Ht}=12 \mathrm{~km})$ are also shown for comparison with the data. $f$, Maximum crosswind cloud width $(y[\mathrm{max}]$; measured as projection to N$\mathrm{S}$ direction) versus distance (measured as projection to E-W direction) to cloud front measured as in $c$ for the May 18, 1980, plinian cloud. Data are consistent to a first order with lateral spreading as an intrusive gravity current while downwind advection at the windspeed is occurring. Data are also consistent with a steadily fed, 15-km-high (Ht varying between 11 and $17 \mathrm{~km}$ ) cloud of roughly constant volumetric flux with little role for atmospheric diffusion or wind shear. Theoretical predictions for different windspeeds at cloud height $(\mathrm{Ht}=15 \mathrm{~km})$ are also shown for comparison with the data. 


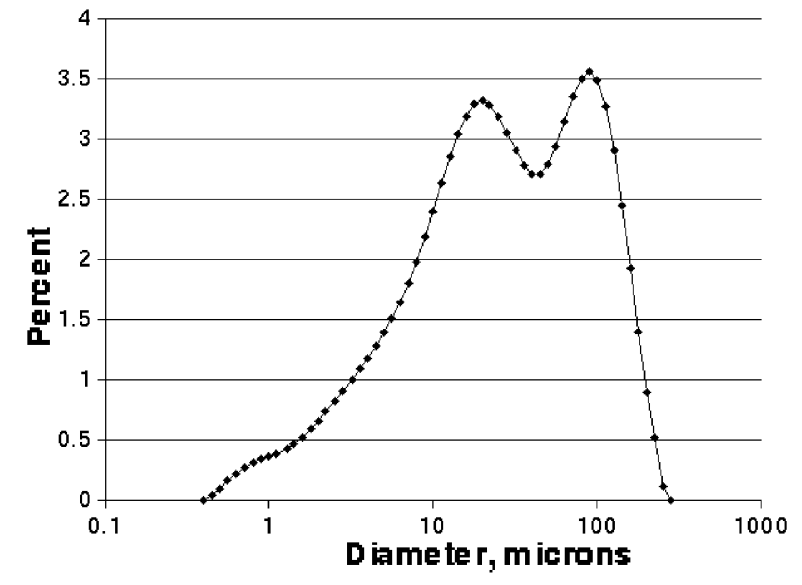

Figure 9. Grain-size distribution (mass, \%) as determined by laser diffraction (Malvern Instruments) for a distal-ash sample located by 44 in figure $7 B$ (data from Riley et al. 1999).

remove a vast majority of the fine ash that resides in volcanic clouds within about the first day or day and a half. The burden (and concentration) of fine ash in volcanic clouds stage 3 is low and may possibly be insufficient to cause engine failure, although damage to the aircraft would occur. Tests of the engine tolerance of ash may be needed to support this suggestion that could serve to restrict the hazard of volcanic clouds to a $1-2 \mathrm{~d}$ period after eruption.

Human Health Effects of Fine Volcanic Ash. Our observations of volcanic clouds are important with respect to the fallout of fine ash that is a potential hazard to human health. Moreover, the presence of silica phases such as cristobalite (Baxter et al. 1999) or even the small size of silicate ash (Norton and Gunter 1999) is potentially harmful to health because of the respirable characteristics of fine ash $<<10 \mathrm{~mm}$ in diameter and especially that $<2.5 \mu \mathrm{m}$ in diameter). The data we have presented on the Spurr clouds shows that a lot of fine ash fell out over Alaska in the stage 2 of the Spurr clouds, and examination of the fallout materials (fig. 8) shows that abundant fine ash is present within the materials of the distal ash blankets. As studies in Idaho (Norton and Gunter 1999) have shown, volcanic ash can be a dominant component of the respirable dust (PM10) for many years after the eruption is over, even in an area that has experienced only light ashfall. Our work suggests that respirable dust studies in distal-ash fall areas would be of interest in assessing the human health hazards. The area of the distal fall blankets and in particular the sec- ondary maximum of fallout thickness should be a target of such future studies.

Radar Detection of Aggregation. Rose et al. (1995b) demonstrated that C-band radar observations of the Spurr clouds were limited to stage 1 and were the result of particle sizes of at least 2 $\mathrm{mm}$. It may be that new generation radar such as Next Generation Weather Radar (NEXRAD; Krohn et al. 1994), which was installed across the United States after the Spurr events, will enable detection of stage 2 aggregation that likely involves individual particle diameters in the range of $1-100 \mu \mathrm{m}$ (but up to perhaps $1500 \mu \mathrm{m}$ ) forming aggregates 100-500 $\mu \mathrm{m}$ (but with maximum diameters up to perhaps $2000 \mu \mathrm{m}$ [see table 1 of Carey and Sigurdsson 1982 and fig. 2 of Bonadonna et al. 1998]). NEXRAD radar measurements could potentially establish the heights and locations for the aggregation and should help clarify its nature and cause.

\section{Conclusions}

Three eruptions of Crater Peak, Mt. Spurr, in 1992 were similar in duration, intensity, volume, and atmospheric conditions. All reached the stratosphere but were mainly dispersed in the upper troposphere. The volcanic clouds were mapped and measured for several days by both TOMS and AVHRR satellite sensors. Each of the three volcanic clouds had more detectable $\mathrm{SO}_{2}$ mass in its second day than in its first day of atmospheric residence, suggesting that some of the magmatic sulfur release was in the form of $\mathrm{H}_{2} \mathrm{~S}$ or that $\mathrm{SO}_{2}$ was temporarily sequestered in ice within the first day of the volcanic cloud and emerged as ice evaporated during fallout. In all three eruptions, the fallout of fine ash $(<25 \mu \mathrm{m}$ in diameter) was very rapid in the first 24 $\mathrm{h}$ of cloud residence, an observation that cannot be explained by fallout as simple, separate particles.

The ash fallout blanket for each eruption was highly elongated, and at least two had a prominent secondary-mass maximum located $150-350 \mathrm{~km}$ downwind. Fallout at these secondary maxima had bimodal fine-skewed size distributions that reflect aggregation of fine particles prior to fallout. The Spurr volcanic clouds exhibited three stages of atmospheric residence. First, the first hour of atmospheric residence was dominated by particle transport, and fallout from the margins of the eruption column and from an advected gravity current generated from it. Rapid fallout of large $(>500 \mu \mathrm{m}$ in diameter) ash and lapilli resulted in heavy fallout near $(<25 \mathrm{~km})$ the volcano, affecting a small area $\left(<\sim 300 \mathrm{~km}^{2}\right)$. Second, after that first hour and during the first day of residence, the Spurr clouds were 
expanding in size because of advection, wind shear, and diffusion by winds but experiencing aggregate fallout that resulted in reduction of the mass of fine $(<25 \mu$ m diameter) ash by $\sim 90 \%$ and in secondarymass fallout maxima regions that affect areas of about $5 \times 10^{4} \mathrm{~km}^{2}$. We suggest that aggregation can reduce the expected three medial/distal segments on $\ln \mathrm{T}$ versus $\mathrm{A}^{1 / 2}$ dispersal diagrams to two segments in dry plinian deposits and only one distal segment in phreatomagmatic deposits. Finally, the remaining several days of atmospheric residence of the Spurr clouds were marked by constant or declining cloud area and slowly declining particle and $\mathrm{SO}_{2}$ masses with losses apparently occurring from the more rapidly moving cloud bases.

Ash-cloud spreading analysis in stage 1 and early stage 2 suggests that the lateral spreading can be accounted for by theory of Bursik et al. (1992) in which lateral spreading is due to gravity flow while the volcanic cloud front is advected at the windspeed at that level. This theory is useful in predicting the shape of the cloud between the upwind leading edge and the location of maximum spreading for $5 \mathrm{~h}$ or so (the same also works for Mount St. Helens), while the position of the front snout of the current is also easily accounted for without invoking diffusion or wind shear. Volcanic clouds are most hazardous in their first few hours, and the first phase of cloud lateral spreading due to gravity flow for VEI $>3$ clouds is typically very rapid. This rapid first phase of spreading importantly constrains the initial conditions for the next stages of spreading due to wind shear and diffusion. We urge those concerned with aircraft safety and developing new volcanic cloud tracking models to take this into account when initializing their advectiondiffusion schemes (eg., those used in volcanic ash advisory centers). These conclusions on cloud spreading should be limited to nonbifurcating VEI $=3$ dry subplinian eruptions until we can analyze more cases.

\section{A C K N O W L E D G M E N T S}

Work on the Spurr eruptions began in 1992 and was greatly aided by the cooperation of the USGS through the Alaska Volcano Observatory, where T. Miller and T. Keith were very helpful. The National Science Foundation and NASA provided funding for the study. G. G. J. Ernst acknowledges an award from the Nuffield Foundation, U.K. T. Neal, R. Helz, and two anonymous reviewers helped us improve the manuscript. M. Watson and L. Mankowski helped with the figures.

\section{RE FER E N C E S C I T E D}

Baxter, P. J.; Bonadonna, C.; Dupree, R.; Hards, V. L.; Kohn, S. C.; Murphey, M. D.; Nicols, A.; et al. 1999. Cristobalite in volcanic ash of Soufrière Hills Volcano, Montserrat, British West Indies. Science 283: 1142-1145.

Bluth, G. J. S.; Rose, W. I.; Sprod, I. E.; and Krueger, A. J. 1997. Stratospheric loading from explosive volcanic eruptions. I. Geol. 105:671-683.

Bluth, G. J. S.; Scott, C. J.; Sprod, I. E.; Schnetzler, C. C.; Krueger, A. J.; and Walter, L. S. 1995. Explosive emissions of sulfur dioxide from the 1992 Crater Peak eruptions, Mount Spurr Volcano, Alaska. Geol. Soc. Am. Bull. 2139:37-46.

Bonadonna, C.; Ernst, G. G. J.; and Sparks, R. S. J. 1998. Thickness variations and volume estimates of tephra fall deposits: the importance of particle Reynolds number. J. Volcanol. Geotherm. Res. 81:173-184.

Bursik, M. I.; Carey, S. N.; and Sparks, R. S. J. 1992. A gravity current model for the May 18, 1980 Mount St. Helens Plume. Geophys. Res. Lett. 19:1663-1666.

Carey, S. N., and Sigurdsson, H. 1982. Influence of particle aggregation on deposition of distal tephra from the May 18, 1980, eruption of Mount St. Helens volcano. I. Geophys. Res. 87:7061-7072.

Casadevall, T. J., ed. 1994. Volcanic ash and aviation safety. Proceedings of the First International Sympo- sium on Volcanic Ash and Aviation Safety. U.S. Geol. Surv. Bull. 2047, 450 p.

Constantine, E. K.; Bluth, G. J. S.; and Rose, W. I. 2000. TOMS and AVHRR sensors applied to drifting volcanic clouds from the August 1991 eruptions of Cerro Hudson. In Mouginis-Mark, P.; Crisp, J.; and Fink, J., eds. Remote sensing of active volcanism. (Vol. 116) Washington, D.C., AGU Geophysical Monographs, 45-64 p.

Doukas, M. P., and Gerlach, T. M. 1995. Sulfur dioxide scrubbing during the 1992 eruptions of Crater Peak, Mount Spurr, Alaska. U.S. Geol. Surv. Bull. 2139, 47 p.

Ernst, G. G. J.; Bursik, M. I.; Carey, S. N.; and Sparks, R. S. J. 1996. Sedimentation from turbulent jets and plumes. I. Geophys. Res. 101:5575-5589.

Gardner, C. A.; Cashman, K. V.; and Neal, C. A. 1998. Tephra fall deposits from the 1992 eruption of Crater Peak, Alaska: implications of clast textures for eruptive processes. Bull. Volcanol. 59:537-555.

Glaze, L. S.; Baloga, S. M.; and Wilson, L. 1997. Transport of atmospheric water vapor by volcanic eruption columns. I. Geophys. Res. 102:6099-6108.

Herzog, M.; Graf, H.-F.; Textor, C.; and Oberhuber, J. M. 1998. The effect of phase changes of water on the development of volcanic plumes. J. Volcanol. Geotherm. Res. 87:55-74. 
Keith, T. E. C., ed. 1995. The 1992 eruptions of Crater Peak vent, Mount Spurr volcano, Alaska. U.S. Geol. Surv. Bull. 2139, 220 p.

Krohn, M. D.; Lemon, L. R.; and Perry, J. 1994. WSR-88D applications to volcanic ash detection. Proceedings of First National NEXRAD Users Conference (October), Norman, Okla.

Krotkov, N. A.; Torres, O.; Seftor, C.; Krueger, A. J.; Kostinski, A.; Rose, W. I.; Bluth, G. J. S.; Schneider, D. J.; and Shaefer, S. J. 1999. Comparison of TOMS and AVHRR volcanic ash retrievals from the August 1992 eruption of Mount Spurr. Geophys. Res. Lett. 26: 455-458.

Krueger, A. J.; Walter, L. S.; Bhartia, P. K.; Schnetzler, C. C.; Krotkov, N. A.; Sprod, I.; and Bluth, G. J. S. 1995. Volcanic sulfur dioxide measurements from the total ozone mapping spectrometer instruments. J. Geophys. Res. 100:14,057-14,076.

Mayberry, G. C.; Rose, W. I.; and Bluth, G. J. S. 2001. Dynamics of the volcanic and meteorological clouds produced by the December 26, 1997, eruption of Soufrière Hills volcano, Montserrat, W.I. In Druitt, T.; Young, S.; and Kokelaar, P., eds. The 1995-99 eruptions of Soufrière Hills Volcano, Montserrat. Spec. Publ. Geol. Soc. Lond., in press.

McGimsey, R. G.; Neal, C. A.; and Riley, C. M. 2001. Maps of the ashfall blankets of the 1992 eruptions of Crater Peak, Mount Spurr, Alaska. U.S. Geol. Surv. Open-File Report.

McNutt, S. R.; Tytgat, G. C.; and Power, J. A. 1995. Preliminary analysis of volcanic tremor associated with 1992 eruptions of Crater Peak, Mount Spurr Volcano, Alaska. U.S. Geol. Surv. Bull. 2139, 161 p.

Neal, C. A.; McGimsey, R. G.; Gardner, C. A.; Harbin, M. L.; and Nye, C. J. 1995. Tephra-fall from the 1992 eruptions of Crater Peak, Mount Spurr Volcano, AK: a preliminary report on distribution, stratigraphy and composition. U.S. Geol. Surv. Bull. 2139, 65 p.

Norton, M. R., and Gunter, M. E. 1999. Relationship between respiratory diseases and quartz-rich dust in Idaho, USA. Am. Mineral. 84:1009-1019.

Pinto, J. P.; Turco, R. P.; and Toon, O. B. 1989. Selflimiting physical and chemical effects in volcanic eruption clouds. J. Geophys. Res. 94:11,165-11,174.

Power, J. A.; Jolly, A. D.; Page, R. A.; and McNutt, S. R. 1995. Seismicity and forecasting of the 1992 eruptions of Crater Peak Vent, Mount Spurr Volcano, Alaska: an overview. U.S. Geol. Surv. Bull. 2139, 149 p.

Pyle, D. M. 1989. The thickness, volume and grainsize of tephra fall deposits. Bull. Volcanol. 51:1-15.

Riley, C. M.; Bluth, G. J. S.; and Rose, W. I. 1999. Characterizing the shapes of pyroclasts in distal fallout material to improve our understanding of fallout rates and transport. Proceedings of the International Union of Geodesy and Geophysics XXII General Assembly, p. B169.

Rose, W. I.; Bluth, G. J. S.; and Ernst, G. G. J. 2000. Integrating retrievals of volcanic cloud characteristics from satellite remote sensors-a summary. Philos. Trans. R. Soc. Lond. A Math. Phys. Sci. 358: 1585-1606.

Rose, W. I.; Delene, D. J.; Schneider, D. J.; Bluth, G. J. S.; Krueger, A. J.; Sprod, I.; McKee, C.; Davies, H. L.; and Ernst, G. G. J. 1995a. Ice in the 1994 Rabaul eruption cloud: implications for volcano hazard and atmospheric effects. Nature 375:477-479.

Rose, W. I.; Kostinski, A. B.; and Kelley, L. 1995b. Real time C band radar observations of 1992 eruption clouds from Crater Peak/Spurr Volcano, Alaska. U.S. Geol. Surv. Bull. 2139, 19 p.

Sarna-Wojcicki, A.; Shipley, S.; Waitt, R. B., Jr.; Dzurisin, D.; and Wood, S. H. 1981. Areal distribution, thickness, mass, volume, and grain size of air-fall ash from the six major eruptions of 1980. In Lipman, P. W., and Mullineaux, D. R., eds. The 1980 eruptions of Mount St. Helens, Washington. U.S. Geol. Surv. Prof. Pap. 1250, 667-681.

Scasso, R. A.; Corbella, H.; and Tiberi, P. 1994. Sedimentological analysis of the tephra from the 12-15 August 1991 eruption of Hudson Volcano. Bull. Volcanol. 56:121-132.

Schneider, D. J.; Rose, W. I.; Coke, L. R.; Bluth, G. J. S.; Sprod, I.; and Krueger, A. J. 1999. Early evolution of a stratospheric volcanic eruption cloud as observed with TOMS and AVHRR. I. Geophys. Res. 104: 4037-4050.

Schneider, D. J.; Rose, W. I.; and Kelley, L. 1995. Tracking of 1992 eruption clouds from Crater Peak/Spurr Volcano using AVHRR. U.S. Geol. Surv. Bull. 2139, 27 p.

Shannon, J. 1996. 3D reconstruction of the Mount Spurr volcanic clouds using AVHRR, TOMS and wind trajectory data. M.S. thesis, Michigan Technological University, Houghton, $95 \mathrm{p}$.

Sorem, R. K. 1982. Volcanic ash clusters: tephra rafts and scavengers. J. Volcanol. Geotherm. Res. 13:63-71.

Sparks, R. S. J.; Bursik, M. I.; Carey, S. N.; Gilbert, J. S.; Glaze, L. S.; Sigurdsson, H.; and Woods, A. W. 1997. Volcanic plumes. New York, Wiley, 574 p.

Textor, C. 1999. Numerical simulation of scavenging processes in explosive eruption clouds. Ph.D. dissertation, Max Planck Institute for Meteorology, Hamburg, 129 p.

Viramonte, J. G.; Becchio, R.; Bolli, M. I.; Petrinovic, I.; and Tejada, R. S. A. 1995. Actividad eruptiva del volcan Lascar: Erupcion 18/24-Abril-1993. Instituto Geonorte, Universidad Nacional de Salta, Argentina.

Wen, S., and Rose, W. I. 1994. Retrieval of sizes and total masses of particles in volcanic clouds using AVHRR bands 4 and 5. I. Geophys. Res. 99:5421-5431.

Woods, A. W. 1993. Moist convection and the injection of volcanic ash into the atmosphere. J. Geophys. Res. 98:17,627-17,636.

Yu, T.; Rose, W. I.; and Prata, A. J. 2002. Atmospheric correction for satellite based volcanic ash mapping and retrievals using "split window" IR data from GOES and AVHRR. J. Geophys. Res., in press. 